\title{
Pengembangan sumber belajar basis data bermuatan conceptual learning untuk meningkatkan pemahaman konsep dan menumbuhkan kemandirian belajar
}

\author{
Azzhan Shahrul ${ }^{1}$, Muladi $^{2}$, Triyanna Widiyaningtyas ${ }^{3}$ \\ 1. Universitas Negeri Malang, Indonesia | azzhans@gmail.com \\ 2. Universitas Negeri Malang, Indonesia | muladi@um.ac.id \\ 3. Universitas Negeri Malang, Indonesia | triyannaw.ft@um.ac.id
}

\begin{abstract}
Abstrak
Mata pelajaran basis data menunjang siswa untuk membangun, mengatur, dan memanipuasi data yang berupa informasi, gambar, video, audio, dan kombinasi dari yang disimpan dalam media elektronik dan diolah sedemikian rupa agar dapat digunakan dengan efektif dan efisien. Berdasarkan observasi awal ditemukan bahwa pemahaman siswa dalam memahami pelajaran basis data masihlah rendah. $70 \%$ siswa merasa bahwa mata pelajaran basis data sulit untuk dipahami. Berdasarkan latar belakang yang telah dipaparkan. Penelitian ini bertujuan untuk mengembangkan Sumber Belajar berupa Modul Ajar dengan muatan Conceptual Learning untuk meningkatkan pemahaman konsep dan menumbuhkan kemandirian belajar pada Siswa. Sumber belajar ini dikembangkan dengan menggunakan Model Pengembangan Analyze, Design, Develop, Implement, Evaluate (ADDIE). Hasil kelayakan dari ahli materi yaitu $81 \%$, validasi ahli media $87,5 \%$, hasil uji coba memperoleh presentase sebesar $87.9 \%$, Peningkatan pemahaman konsep siswa mendapatkan nilai post test lebih tinggi 53\% dari rata-rata nilai pre test, dan kemandirian belajar mendapat rata-rata sebesar $82.04 \%$.
\end{abstract}

Kata Kunci

Pengembangan, Sumber Belajar, Basis Data, Conceptual Learning

TEKNO Vol. 28 No 1, p25-33 | Jurusan Teknik Elektro, Universitas Negeri Malang, Indonesia | Maret 2018

A. Shahrul, Muladi, T. Widiyaningtyas | Pengembangan sumber belajar basis data bermuatan judul... 


\section{TEKNO Junnal Teknologi Elekrro dan Kejuruan}

http://journal2.um.ac.id/index.php/tekno | ISSN 1693-8739

\section{Pendahuluan}

Basis data merupakan salah satu mata pelajaran yang diajarkan pada Program Keahlian Rekayasa Perangkat Lunak di Sekolah Menengah Kejuruan. Berdasarkan hasil observasi dan kajian literatur yang telah dilakukan di SMK PGRI 3 Malang, ditemukan permasalahan yang menunjukan bahwa kurang berhasilnya pemahaman konsep siswa terhadap mata pelajaran basis data, informasi tersebut didapatkan saat proses observasi dan pengamatan dalam pembelajaran didalam kelas dan dalam kegiatan praktikum di laboratorium.

Ketika kegiatan pembelajaran berlangsung, guru menggunakan pendekatan scientific sebagai berikut: (1) menyampaikan materi secara lisan serta menggunakan media papan tulis untuk menulis, menggunakan notebook dan proyektor untuk menampilkan slide materi pokok pembelajaran dan menuntun siswa saat melakukan kegiatan praktikum. (2) membuka sesi tanya jawab dan diskusi tentang materi yang belum dipahami oleh siswa; (3) memberikan tugas mengerjakan soal latihan dan studi kasus praktikum; (4) pada saat mengerjakan latihan dan studi kasus, guru meninggalkan ruang laboratorium supaya siswa dapat mengerjakan secara mandiri; dan (5) Guru kembali dan meminta hasil latihan dan studi kasus untuk dikumpulkan.

Pembelajaran yang dilakukan guru seperti yang disebutkan diatas memiliki beberapa kelemahan, diantaranya: (1) tidak semua siswa dapat menerima dan menangkap materi pembelajaran dengan metode ceramah karena metode ini cenderung membosankan dan kurang menarik; (2) dengan metode ceramah dan instruksi akan lebih sering terjadi kesalahan konsep pemahaman siswa; dan (3) siswa akan lebih rentan lupa dengan apa yang disampaikan oleh guru.

Informasi kedua didapatkan dari hasil wawancara dengan guru pengajar mata pelajaran Basis data dan sejumlah siswa. Guru mengatakan bahwa dalam proses pembelajaran tingkat pemahaman siswa berbeda-beda. Ada siswa yang cepat menangkap materi dan ada juga yang masih lemah selebihnya berada pada tingkatan sedang. Tingkatan tersebut dinyatakan oleh guru dari hasil tugas latihan yang dikerjakan siswa dan tanya jawab saat proses pembelajaran. Bahkan guru harus mengulang berkali-kali materi yang telah disampaikan. Maka perlu adanya penambahan materi yang mendukung proses belajar siswa secara mandiri.

Informasi ketiga diperoleh dari hasil pengisian angket yang diberikan kepada siswa. Dari data tersebut didapatkan bahwa $70 \%$ siswa masih memiliki pemahaman yang lemah dalam mata pelajaran basis data. Maka dari itu perlu adanya pengembangan modul ajar untuk meningkatkan pemahaman siswa dengan metode Conceptual Learning untuk meningkatkan pemahaman konsep serta dapat menumbuhkan kemandirian belajar siswa.

Lingkungan sekolah SMK PGRI 3 Malang dengan sarana prasarana yang dapat dikatakan lengkap dianggap akan mampu digunakan untuk pengembangan sumber belajar Basis data ini khususnya pada siswa kelas X Jurusan Rekayasa Perangkat Lunak. Pengembangan sumber belajar dapat membantu siswa untuk memahami materi dengan metode Conceptual Learning 


\section{TEKNO Jumal Teknologi Elekrto dan Kejuruan}

http://journal2.um.ac.id/index.php/tekno | ISSN 1693-8739

yang dapat membantu siswa dalam Meningkatkan Pemahaman Konsep serta menumbuhkan kamandirian belajar siswa.

Pengembangan sumber belajar yang dikembangkan akan disesuaikan dengan sarana dan prasarana yang ada disekolah dan yang dimiliki oleh masing-masing siswa. Berdasarkan hasil dari observasi yanng telah dilakukan ditemukan bahwa $100 \%$ siswa memiliki perangkat yang dapat digunakan untuk mengakses browser. Selain itu dari pihak sekolah juga telah membagikan Smartphone/ Tablet kepada semua siswa disekolah. Setiap sudut sekolah juga disediakan jaringan internet/fasilitas Wifi sehingga siswa akan lebih mudah mengakses browser untuk mencari tambahan dan pengetahuan baru. Maka sumber belajar ini akan mampu membantu siswa dalam memperoleh materi tentang Basis data yang dilengkapi dengan metode Conceptual Learning untuk Meningkatkan Pemahaman Konsep pada pemahaman siswa. Sumber belajar ini selain diakses didalam kelas juga dapat diakses diluar kelas, sehingga menjadi sumber belajar siswa dimanapun dan kapanpun mereka berada. Sumber belajar ini akan dikembangkan dengan modul basis data yang berbasis website.

\section{Metode}

Model penelitian dan pengembangan yang digunakan adalah model pengembangan ADDIE merupakan model penelitian dan pengembangan yang dikembangkan oleh (Dick and Carry 1996). Ada lima tahapan dalam pengembangan ADDIE yaitu: (1) analyze/analisis kebutuhan; (2) design/desain; (3) development/pengembangan produk; (4) implementation/implementasi; dan (5) evaluation/evaluasi dari setiap tahapan. Diagram Model Pengembangan ADDIE ditunjukkan pada Gambar 2.1.

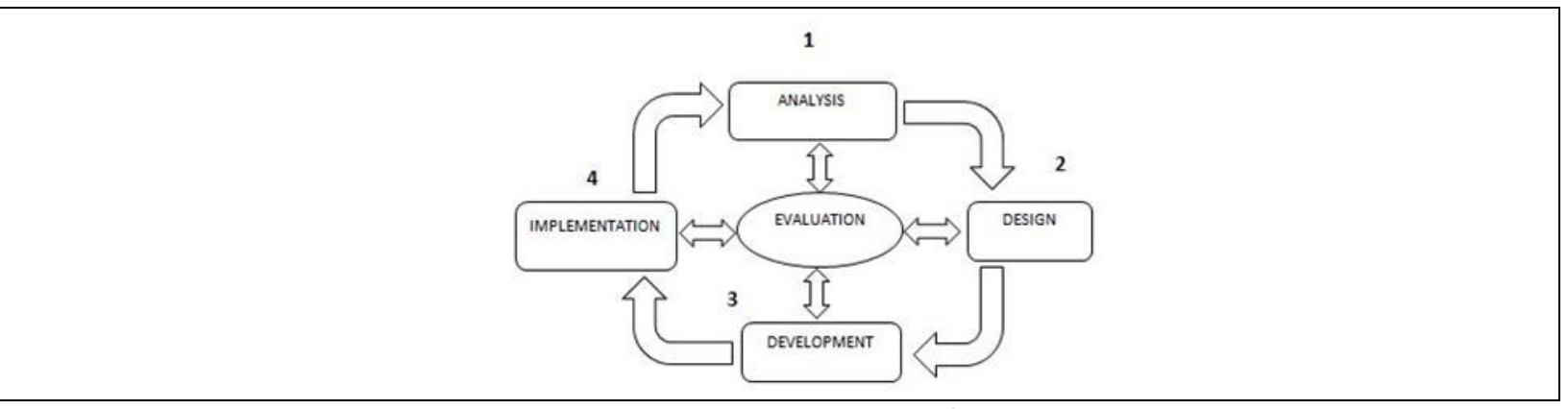

Gambar 2.2 Diagram Tahapan ADDIE (Sumber: Branch 2009)

Dari diagram diatas model ADDIE dapat diketahui bahwa terdapat beberapa langkah-langkah tahap pengembangan. Seperti yang dikemukakan oleh (Branch 2009) seperti berikut: 


\section{TEKNO Jumal Teknologi Elekrro dan Kejuruan}

http://journal2.um.ac.id/index.php/tekno | ISSN 1693-8739

\section{Analysis}

Analysis (analisa), tahapan ini bertujuan untuk mengidentifikasikan suatu keadaan yang memungkinkan untuk ditemukannya permasalahan yang membutuhkan solusi untuk menyelesaikannya. Dalam tahapan analisis memiliki langkah-langkah diantaranya: (1) menganalisis masalah; (2) menentukan arah tujuan pengembangan; (3) menganalisis kebutuhan; (4) mengidentifikasi sumber daya yang akan dibutuhkan; (5) menentukan cara untuk memecahkan permasalahan; dan (6) merencanakan pengelolaan proyek.

Tahapan analisis merupakan tahapan yang pertama yang harus dilakukan oleh peneliti, diantaranya adalah menganalisis siswa, pembelajaran, serta media untuk menyampaikan bahan ajar. Langkah-langkah dalam tahapan analisis ini setidaknya meliputi siswa, menentukan materi ajar, menentukan standar kompetensi yang akan dicapai, dan menentukan media yang akan digunakan sesuai dengan sumber daya yang ada (Fadli 2012).

2. Design

Design (desain), tahapan ini berfungsi untuk merancang bentuk serta tampilan produk yang dikembangkan. Selain itu, tahapan desain juga merancang model uji kelayakan produk. tahapan ini memiliki langkah-langkah sebagai berikut: (1) merancang konsep desain produk, (2) mengembangkan desain produk, (3) menyusun langkah pengujian, dan (4) menyusun isi instrumen validasi produk.

Tahapan desain ini merupakan inti dari tahapan analisis karena mempelajari permasalahan yang telah dianalisis kemudian mencari solusi alternative.

3. Development

Development (pengembangan), pada tahapan ini berfungsi untuk membuat produk dengan sumber daya yang telah ditentukan sesuai kebutuhan. Tahapan pengembangan merupakan proses mewujudkan desain menjadi kenyataan. Jika dalam desain memerlukan software berupa multimedia pembelajaran, maka multimedia tersebut harus dikembangkan. Tahapan ini memiliki langkah-langkah sebagai berikut: (1) mengembangkan konten, (2) mengembangkan media pendukung produk, (3) penyusunan produk (buku manual), (4) melakukan pengujian dan validasi produk oleh ahli materi dan ahli media.

4. Implementation

Implementation (Implementasi), tahapan ini berfungsi untuk menerapkan produk yang telah dibuat kepada subjek (siswa). Dalam tahapan ini memiliki langkah-langkah sebagai berikut: (1) produk yang telah dikembangkan, (2) menyiapkan sumber daya yang mendukung penggunaan produk, dan (3) melakukan koordinasi dengan siswa sebagai subjek yang melakukan uji coba.

Tahapan implementasi adalah langkah nyata untuk menerapkan sistem pembelajaran yang telah dikembangkan. Artinya, pada tahapan ini semua yang telah dibuat diimplementasikan kepada subjek (siswa). 


\section{TEKNO Jumal Teknologi Elekrro dan Kejuruan}

http://journal2.um.ac.id/index.php/tekno | ISSN 1693-8739

\section{Evaluation}

Evaluation (Evaluasi), tahapan ini berfungsi untuk memperoleh hasil dari penilaian kualitas dari produk yang telah dikembangkan. Tahap ini memiliki langkah-langkah sebagai berikut: (1) menentukan kriteria evaluasi, (2) memilih alat evaluasi, dan (3) melakukan evaluasi. Untuk mendapatkan hasil evaluasi yang objektif, maka tahapan evaluasi dilakukan secara bertahap dari awal pengembangan produk.

Data hasil pengujian diperoleh melalui pengolahan data pada angket validasi dan angket uji coba, serta kritik dan saran yang dapat dijadikan sebagai pedoman dalam melakukan perbaikan. Angket penilaian responden, disusun dengan menggunakan kriteria dengan menggunakan kriteria penilaian skala likert. Pada skala likert awalnya skor tertinggi tiap butir 5 dan rendah 1.

Ketika pengukuran sering terjadi kecenderungan responden memilih dalam kategori 3 , untuk menghindari hal itu skala likert dimodifikasi dengan hanya menggunakan pilihan 4 pilihan yaitu 4 (Sangat baik); 3 (Baik); 2 (Cukup); 1 (Kurang). Teknik analisis data dalam penelitian ini menggunakan analisis deskriptif persentase melalui pemaparan data atau simpulan data yang diolah menggunakan teknik presentase. Rumus persentase ditunjukan pada Pers. (1).

$$
V=\frac{\sum T S E V}{\sum S-\max } X 100 \%
$$

Pers. (1)

Keterangan:

- V : Persentase data per-butir soal.

- $\quad$ TTsev : Tolal Skor Empirik Validator.

- $S-\max$ : Skor maksimal yang diharapkan.

Kriteria penilaian sebagai dasar pengambilan keputusan untuk merevisi media pembelajaran digunakan kriteria kelayakan yang ditunjukkan pada Tabel 1 (Sugiono 2010).

Tabel 1. Tabel Kriteria Kelayakan Produk Pengembangan

\begin{tabular}{cll}
\hline Persentase (\%) & Tingkat Kelayakan & Keterangan \\
\hline $75,01-100,00$ & Valid & Dapat digunakan tanpa revisi \\
$50,01-75,00$ & Cukup valid & Dapat digunakan dengan revisi kecil \\
$325,01-50,00$ & Tidak Valid & Tidak layak digunakan \\
$0-25,00$ & Sangat tidak valid & Tidak boleh digunakan \\
\hline
\end{tabular}

Rumus untuk menghitung efektifitas sumber belajar dalam meningkatkan pemahaman konsep siswa ditunjukan pada Pers. (2).

TEKNO Vol. 28 No 1, p25-33 | Jurusan Teknik Elektro, Universitas Negeri Malang, Indonesia | Maret 2018

A. Shahrul, Muladi, T. Widiyaningtyas | Pengembangan sumber belajar basis data bermuatan judul... 
http://journal2.um.ac.id/index.php/tekno | ISSN 1693-8739

$$
\mathrm{P}=\frac{(\bar{X} \text { Post test }-\bar{X} \text { Pre test })}{\bar{X} \text { Pre test }} X 100 \%
$$

Keterangan:

- Pre test : rata-rata nilai pre test siswa.

- Post test : rata-rata nilai post test siswa.

- $100 \%$ : konstanta.

Pada Tabel 2, kriteria penilaian sebagai dasar pengukuran kemandirian siswa yang ditinjau dari aspek inisiatif, tanggung jawab, percaya diri, motivasi, dorongan internal, dan perencanaan belajar (Mujiman 2011).

Tabel 2. Kriteria Kemandirian Siswa

\begin{tabular}{cl}
\hline Persentase (\%) & $\begin{array}{l}\text { Tingkat } \\
\text { Kelayakan }\end{array}$ \\
\hline $75,01-100,00$ & Sangat Tinggi \\
$50,01-75,00$ & Tinggi \\
$325,01-50,00$ & Cukup Tinggi \\
$0-25,00$ & Rendah \\
\hline
\end{tabular}

\section{Hasil}

Penelitian pengembangan ini telah dilakukan validasi ahli media, ahli materi, dan uji coba. Tahapan validasi digunakan untuk mengetahui kekurangan serta tingkat validitas dari sumber belajar. Angket uji coba, serta kritik dan saran yang dapat dijadikan sebagai pedoman dalam melakukan perbaikan oleh peneliti. Pe-ngolahan data untuk menentukan tingkat validitas maupun kelayakan produk yang dikembangkan.

Hasil kelayakan sumber belajar yang diperoleh dari ahli materi yaitu 81\% (kategori "sangat layak"), hasil dari validasi ahli media $87,5 \%$ (kategori "sangat layak"), sedangkan hasil uji coba yang telah dilakukan memperoleh presentase sebesar $87.9 \%$ dengan (katagori "Sangat layak"). Rata-rata hasil pre-test sebesar 59.8. Kemudian rata-rata post-test sebesar 92. Sehingga dapat disimpulkan bahwa nilai post-test lebih tinggi $53.8 \%$ dari rata-rata nilai pre-test. kemandirian belajar siswa mendapat persentase sebesar $82.04 \%$.

a) Hasil validasi ahli media.

Berdasarkan tabel kategori kelayakan tabel hasil penilaian ahli materi menunjukkan hasil dengan rata-rata sebesar $81 \%$. maka dapat dinyatakan materi dalam sumber belajar dinyatakan valid dan kriteria kelayakan "Sangat Layak". 


\section{TEKNO Jumal Teknologi Elektro dan Kejuruan}

http://journal2.um.ac.id/index.php/tekno | ISSN 1693-8739

b. Hasil validasi ahli materi

Hasil penilaian media pembelajaran oleh Ahli Media didapat persentase kelayakan dengan ratarata $87,5 \%$ maka media pembelajaran dalam kriteria kelayakan "Sangat Layak" dan dinyatakan valid dan dapat digunakan dalam proses pembelajaran.

c. Hasil uji coba

hasil Uji Coba Produk dapat diketahui bahwa kriteria Perangkat lunak mendapat persentase sebesar $84.1 \%$, kriteria Desain pembelajaran mendapat persentase sebesar $89.4 \%$, dan kriteria Komunikasi visual mendapat persentase sebesar $88.7 \%$. sehingga diperoleh rata-rata persentase sebesar $87.9 \%$. berdasarkan kriteria yang diterapkan, jika rentangan persentase rata-rata sebesar $70.01 \%-100 \%$, maka uji coba produk dinyatakan valid.

d. Hasil pemahaman konsep

Rata-rata hasil pre-test sebesar 59.8. Kemudian rata-rata post-test sebesar 92. Sehingga dapat disimpulkan bahwa nilai post-test lebih tinggi $53.8 \%$ dari rata-rata nilai pre-test.

e. Hasil kemandirian belajar

Hasil kemandirian belajar siswa mendapat persentase rata-rata per aspek sebesar $82.04 \%$. Berdasarkan pengujian yang dilakukan, pengembangan sumber belajar basis data dengan muatan Conceptual Learning untuk meningkatkan pemahaman konsep dan menumbuhkan kemandirian belajar siswa pada kelas X Jurusan Rekayasa Perangkat Lunak di SMK PGRI 3 Malang secara keseluruhan pada aspek rekayasa perangkat lunak, media pembelajaran, dan komunikasi visual dapat dikatagorikan sangat layak, sehingga sumber belajar berbasis web ini dapat digunakan sebagai sumber belajar untuk membantu proses pembelajaran.

\section{Kesimpulan}

Berdasarkan uraian hasil penelitian, maka dapat dikemukakan kesimpulan sebagai berikut:

- Penelitian pengembangan ini menghasilkan produk berupa media pembelajaran berbasis web untuk Mata Pelajaran Basis data di Sekolah Menengah Kejuruan kelas X Jurusan Rekayasa Perangkat Lunak yang dapat di akses dengan alamat http://www.sinau.online/website.

- Sumber belajar ini memuat materi basis data dengan sub materi pemograman MySQL. Produk ini telah dinilai dari aspek perangkat lunak, aspek media pembelajaran, dan aspek komunikasi visual.

- Pengembangan produk ini memiliki dua komponen utama yang terdiri dari Pengembangan Materi Basis data, dan latihan dengan pedoman Silabus Kurikulum 2013. Serta, Pengembangan Media meliputi Interface Web diantaranya: Pengembangan Login, 


\section{TEKNO Junal Teknologi Elektro dan Kejuruon}

http://journal2.um.ac.id/index.php/tekno | ISSN 1693-8739

Halaman Utama, Halaman Materi, Halaman Evaluasi, Halaman Live Editor, dan Halaman lihat koreksi nilai evaluasi.

- Hasil pengembangan sumber belajar basis data bermuatan Conceptual Learning untuk Meningkatkan Pemahaman Konsep dan menumbuhkan kemandirian belajar pada siswa kelas X Jurusan Rekayasa Perangkat Lunak di SMK PGRI 3 Malang.

\section{Daftar Rujukan}

Ali, Mohammad dan Mohammad Asrori. 2005. Psikologi Remaja Perkembangan Siswa. Jakarta: PT Bumi Aksara.

Arends, Richard I. 2007. Learning to Teach.Boston: McGraw-Hill.

Departemen Pendidikan dan Kebudayaan. 1983. Teknologi Instruksional. Jakarta: Ditjen Dikti, Proyek Pengembangan Institusi Pendidikan Tinggi.

Depdiknas. 2008. Panduan Pengembangan Bahan Ajar. Jakarta: Depdiknas.

Djamarah, Syaiful Bahri \& Aswan, Zain. 2010. Strategi Belajar Mengajar. Jakarta: Rineka Cipta.

Sugiono. 2010. "Metode Penelitian Pendidikan: Pendekatan Kuantitatif, Kualitatif, Research \&

Development". Bandung: Alfabeta

Branch, R.M. 2009. Instructional Design: The ADDIE Approach. London: Springer

Fathansyah. 2002. Buku Teks Ilmu Komputer Basis Data. Bandung: Informatika.

Depdiknas. 2004. Pedoman Merancang Sumber Belajar. Jakarta.

Mulyana, Deddy. 2007. Conceptual Learning. Bandung : PT. Remaja Rosdakarya

Hahn Ulrike \& Ramscar Michael.2001. Similarity and Categorization. Oxford: OUP Oxford.

Hung, W. 2006. The 3C3R Model: A Conceptual Framework for Designing Problems in PBL. Interdisciplinary Journal of Problem-Based Learning, (1), 55-77. Dari http://doi.org/10.7771/1541-5015.1006.

Kadir, Abdul. 2003. Konsep dan Tuntunan Praktis Basis Data. Yogyakarta: Andi.

Liliawati Winny \& Puspita Erna. 2010. Efektivitas Pembelajaran Berbasis Masalah Dalam Meningkatkan Keterampilan Berfikir Kreatif Siswa. Prosiding Seminar Nasional

Fisika 2010. Universitas Pendidikan Indonesia. Bandung. Tidak diterbitkan.

Majid, Abdul. 2006. Perencanaan Pembelajaran. Bandung: Remaja Rosdakarya.

Miarso, Yusufhadi. 2004. Menyemai Benih Teknologi Pendidikan. Jakarta : Kencana Prenada.

Mujiman, Haris. 2011.Belajar Mandiri (Self-Motivated Learning). Solo: UNS Press.

Prastowo, Andi. 2013. Pengembangan Bahan Ajar Tematik. Yogyakarta: Diva PRESS.

Rusman. 2011. Model-Model Pembelajaran: Mengembangkan Profesionalisme Guru. Jakarta: PT. Raja Grafindo Persada. 


\section{TEKNO Junnal Teknologi Elekrto dan Kejuruan}

http://journal2.um.ac.id/index.php/tekno | ISSN 1693-8739

Seels, B. B., \& Richey, R. C. 1994. Teknologi pendidikan definisi dan kawasanya.Washington, DC: Association for Educational Communications and Technology.

Semiawan, C. 1992. Pendekatan Keterampilan Proses. Jakarta: PT. GramedianWidiasarana Indonesia.

Stephens R \& Plew Ronald. 2000. Database Design. Indiana: Sams Publishing.

Sukarno, Anton. 1989. Ciri-Ciri Kemandirian Belajar. Jakarta: Kencana Prenada Media.

Tirtarahardja, Umar dan Sulo, La. 2005. Pengantar Pendidikan. Jakarta: Rineka Cipta.

Uno, B. Hamzah. 2011. Teori Motivasi dan Pengukurannya: Analisis di Bidang Pendidikan. Jakarta: Bumi aksara.

Wina, Sanjaya. 2010. Strategi Pembelajaran Berorientasi Standar Proses Pendidikan. Jakarta: Kencana.

Zacks, J. M., \& Tversky, B. 2001. Event Structure in Perception and Conception. Psychological Bulletin, 127, 3-21. 